\title{
A NEW SPECIES OF PHLOEONEMUS FROM PUERTO RICO (COLEOPTERA: COLYDIIDAE)
}

\author{
By \\ W. S., FISHER

\begin{abstract}
Bureau of Entomology and Plant Quarantine
Agricultural Research Administration

United States Department of Agriculture
\end{abstract}

In a small collection of Coleoptera received for identification from L. E. Martorell the following new species was found.

\section{Phloeongarus martorelit, new species}

Oblong-elongate, rather strongly flattened, not distincly pubescent, dark reddish brown, the antennae and palpi slightly paler.

Head broad, flat, sides dilated, the dilation extending backward to middle of eyes, broadiy, vaguely depressed on each side toward eyes, obtusely earinate above eyes, the carina extending from posterior fourth of eye to a short distance in front of eye; surface very finely, densely granulose, finely, shallowly punctate anteriorly, finely, densely, irregularly reticulate porteriorly.

Pronotum strongly transverse, much wider than head, widest near posterior angles; sides slightly rounded, nearly parallel along basal half, vaguely converging anteriorly, the margins finely crenulate; apical margin deeply emarginate, broadly rounded and thickened at middle; apical angles projecting and rather acute; base slightly arcuate at middle, vaguely sinuate on each side; posterior angles obtusely rounded; disk moderately convex, broadly flattened toward lateral margins, with three obtusely rounded, longitudinal costae on each side of middle, median one extending from base to apex, abruptiy bulging externally at middle and connected posteriorly to the second costa, which extends backward to base, and the third costa vaguely sinuate, extending from base to apex; surface rather coarsely, densely granulose, the granules very irregular in shape, and contiguous at some places. 
Elytra subequal in width to pronotum; sides parallel to apical fourth, then arcuately converging to tips, which are conjointly broadly rounded, the lateral margins acute and vaguely crenulate. Each elytron with five sharply defined, longitudinal costae; sutural and second costae extending from base to apex; third and fourth costae extending from base to near apex; fifth costa extending backward from humerus, and comnected to lateral margin hear apex; intervals between costae (except lateral one) with two rows of rather coarse punctures, separated from one another by about their own diameter, and the interval between punctures in each row with a narrow, longitudinal carina exending from base of one puncture to apex of following puncture. the interval between rows of punctures nearly smooth.

Abdomen beneath more or less irregularly imbricate-puncture; prothorax coarsely, transversely rugose.

... Length 4.7-6 mm., width 2-2.7 mm.

Type locolity. — Guánica. Puerto Rico.

Type and paratypes. - In the United States National Museum, No. 56541. Paratypes in the collection of L. F. Martorell.

Described from ten specimens (one type) all collected at the type locality, January 31, 1940, on the gummy exudations on the trunks of Zanthoxylon flavum trees, by L. F. Martorell.

This species is closely allied to Phloeonemus haroldi Reitter, described from Cuba, but it differs from that species in being larger, in having the longitudinal costae on the elytra not interrupted, the carinae above the eyes obtusely rounded on the tops, and the costae on the pronotum more distinct with the lateral one on each side vaguely sinuate. 